\title{
How to Regain Public Trust in Audit Firms? The Case of the Financial Reporting Council
}

\begin{abstract}
This study aims to provide a better understanding of the role of the Financial Reporting Council (FRC) in restoring public trust in audit profession in the UK. It analyses the views of partners in the Big 4 audit firms on this role. This study identifies three main strategies to promote trust and enhance the choice of auditors in the UK audit market. These strategies are improving audit quality, increasing the transparency of the big audit firms and reducing the barriers to competition in the audit market. The findings suggest that partners of the Big 4 believe that the FRC's projects effectively participate in improving audit quality as well as providing wider information about the audit firms to the public. However, different actions need to be taken to enhance the choice in the market.
\end{abstract}

Key words: UK audit market - Audit regulations - Big 4 firms

\section{Introduction}

The independent oversight of the audit profession has become a global phenomenon in the last decade. Independent regulators have undergone 50 years of self-regulation (Defond, 2005).

The Financial Reporting Council (FRC) is one of those new regulators, which has become, in 2004, the unified independent regulator for corporate reporting and governance. It aims to promote confidence in corporate reporting and governance, exercising its functions through six operating bodies ${ }^{1}$. The Auditing Practices Board and the Professional Oversight Board are the most relevant bodies regulating the audit profession (FRC, 2009). Despite the FRC's efforts to restore public confidence, trust in auditors arguably needs to be regained (ICAEW, 2012). Following the UK financial crisis in 2008, auditors lacked independence and objectivity; regulatory actions are needed to mitigate the risk of further collapses (Sikka, 2009).

Since 2005, the UK government has been concerned about increased concentration of the Big 4 firms in auditing the large listed companies in the capital market (FTSE 100, and FTSE 350). The Big 4 audit $99 \%$ of the largest UK listed companies and their audit fees represent 99\% of the audit fees in the FTSE 350 companies (Oxera, 2006). The Market Participants Group (MPG) was established and specific projects and regulations have since been implemented to enhance the choice in the UK audit market, but there is little evidence of progress in a highly concentrated UK market (FRC, 2010: b).

This study examines the success of the new UK audit regulators work to regain the public trust, while exploring auditors' perceptions of the FRC's effectiveness. Understanding the FRC's role in promoting public confidence and auditors' good perceptions of the FRC can bridge the expectation gap between auditors and regulators. They should enhance the effectiveness of applying audit regulations in the audit market to create more convictions and less resistance in implementing them. It is worth noting that investors' perception should also be considered, but this topic is beyond the scope of this study.

\footnotetext{
${ }^{1}$ The six operating bodies are: Accounting Standards Board (ASB), Auditing Practices Board (APB), Board for Actuarial Standards (BAS), Professional Oversight Board (POB), Financial Reporting Review Panel (FRRP), and Accounting and Actuarial Discipline Board (AADB).
} 
An analysis of the FRC's efforts may help auditors to identify what they are expected to do to improve the reliability of information provided in the capital market. Audit committees can get a better understanding of the criteria they need to improve the process of auditors' choice. Auditors will also better understand how and why current audit regulations have been issued. This may improve their satisfaction with regulations and standards, and their efficient implementation. Furthermore, we believe that audit regulators need to get feedback additional to the formal feedback they receive to improve their performance and current regulations. Formal feedback is beneficial, but auditors may not say everything in formal documents ${ }^{2}$. The confidentiality assurance given to the interviewees of this study maximises the value of this feedback. Here participants understand that no names or firms will be disclosed and nothing can stop them from freely criticising the regulators' performance.

The remainder of this paper is organised as follows. Section 2 reviews previous studies and explains the extent to which this study contributes to the current debate. Section 3 details the research methodology. Sections 4, 5, and 6 discuss, develop and analyse the core categories of the emerged theory. The final section sets out our conclusions.

\section{Prior research}

The independent oversight of the audit profession has been examined from different perspectives. The functions of the audit oversight system established for the first time in the U.S market have been examined in the literature (DeFond and Francis, 2005; Bather and Burnaby, 2006; Abernathy, et al., 2013). Hazgui et al. (2011) examine the influence of the Public Company Accounting Oversight Board (PCAOB) and its working approach on European audit regulators (i.e. France). They argue that the regulatory regime of PCAOB constitutes a "strong driver" to shape the structure of European inspectors' authorities. However, these studies neither analyse the independent regulators efforts nor discuss the auditors' views on such efforts. This study analyses audit regulatory projects in a major European country (i.e. the UK).

The effects of the new system on the audit market have dominated the literature in the last decade (Hope and Langli, 2010; Hoitash et al., 2008). Auditors have become more conservative and follow more rigid policies to accept or continue with clients (Patterson and Smith, 2007). The number of qualified audit reports has increased (Geiger and Raghunandan, 2005) and the amount of fraud has decreased (Patterson and Smith, 2007). Public interests have been intensively considered by regulators and audit firms when compared with the selfregulated stage (Suddaby et al., 2007). However, to what extent are such effects desired? What do regulators really aim to achieve as a result of their projects? And do their projects achieve their objectives? Answering such questions can be a basis for a meaningful evaluation of the regulators' performance.

Some studies have compared audit regulators post-Enron and their pre-Enron peers in different countries (Casterella et al., 2009; Pierce and Sweeney, 2004). Independent regulators are arguably more effective in monitoring audit markets as a result of the power of their sanctions. New relationships have been identified between the new regulatory bodies and other institutions (such as professional bodies and Big 4 firms) (Humphrey et al., 2009; Carson, 2009; Cooper and Robson, 2006). The mutual influence among different players has

\footnotetext{
2 "We cannot criticize our regulators" - one of the Big 4 firms' partners in his speech in the Auditing and Assurance Conference (AAC) that was held in London on the $17^{\text {th }}$ and $18^{\text {th }}$ of May 2012 , organised by the special group of Auditing, British Accounting and Finance Association (BAFA).
} 
been examined (Shapiro and Matson, 2008) and independent audit oversight has been criticised as many of its regulators are retired partners of the Big 4 firms. This is a mean of dominating the regulatory bodies by the Big 4 firms and a regression to the self-regulated era.

Few studies have analysed the working approaches of Independent Audit Oversight Boards in different environments. For example, the PCAOB has given more attention to protect the auditor's independence and mitigates risks of management pressures (Bather and Burnaby, 2006). The US audit regulators have prohibited auditors from providing some particular assurance services to their audit client. Consequently, audit regulators in other regions (i.e. Norway) have taken a similar action and apply more restrictions on the provision of non-audit services (Eilifsen and Knivsflå, 2013). This is not the case in every region where, in the UK for example, audit regulators follow the safeguards approach; meaning that auditors can provide many of non-audit services to their audit clients once they assure that the relevant safeguard is applicable. But independence is not everything for rebuilding investors' trust in auditors; Gradison and Boster (2010) argue that the PCAOB protect public interests by improving the accuracy and reliability of corporate disclosures. However, Evans et al. (2011) suggest that the PCAOB should provide greater transparency in their reports to serve the public (i.e. investors and audit committees).

In Europe, a number of strategies have been followed by oversight authorities to rebuild public trust in auditors. For example, improving audit quality (Duff, 2009), strengthening auditors' independence, enhancing corporate governance (Cuebas, 2010; Ojo, 2007), and increasing transparency and public disclosures of provided information in the capital market (IOSCO, 2010) are the main strategies identified to achieve this aim.

In the UK, the literature suggests that the FRC's supervision helps the audit market to be more quality oriented (Oxera, 2006); audit quality becomes a core value inside the UK audit firms (Hanney, 2006) and overrides other financial motivations (Duff, 2009). However, there is no one agreed definition for the audit quality in the literature and even the FRC's Audit Quality Framework (2008) has been criticised (Knechel, 2009).

In addition, more information about the Big 4 firms and their relations with their global networks has been called for (Basel, 2008; FRC, 2007). The global structure of the Big 4 networks and their national firms have not been widely examined (Basel, 2008). Governance of the Big 4 firms is seen as black boxes that need to be more understandable (IOSCO, 2010).

To sum up, the FRC, as a unified audit regulator in the UK, aims to promote public confidence in the capital market including the audit profession (FRC, 2007). Thus, how could this confidence be promoted? This study analyses the main projects issued by the FRC. Such analysis can provide a better understanding of how the regulators work to enhance the reliability of audit reports in a non-US market and whether these regulations have achieved their aim.

\section{Research methodology}

Two objectives have been identified in this study: to analyse the FRC's strategies to promote public trust in auditors and to discuss practitioners' perceptions of the FRC's efforts. We use a documentary analysis to analyse the FRC's projects and its working approach. However, analysing published documents is not enough to explore auditors' perceptions on the FRC's efforts. Thus, we used interviews to collect relevant data to understand practitioners' perceptions of the FRC's efforts. Interviews allow access to what is going on 'behind the 
scenes' and interviewees can explain the actuality of their experiences in a complex environment.

The absence of prior research (LoBiondo-Wood and Haber, 1994) and the nature of the research questions, which start with what and how (Strauss and Corbin, 1998), support the use of qualitative data in this study. Furthermore, this study depends on the perceptions of the main participants toward the FRC's strategies in rebuilding public trust ${ }^{3}$. Parker and Roffey (1997) argue that studies which begin with predefined operational variables exclude the possibility of identifying new variables or categories of data, or a more meaningful analysis of the relationships between variables.

Research data was gathered by conducting 17 semi-structured interviews (six interviews with the top management of FRC's members and 11 interviews of executive partners of the Big 4 firms in the UK). Each interview took from one to two hours. Interviewees were asked open questions to explore the current efforts of the FRC to improve the audit profession and their perceptions of these efforts. Gathering data from different groups of participants (regulators and auditors particularly) enables us not only to discuss different views on the role of independent regulators in promoting confidence in auditors, but also to analyse these views and provide a better understanding of this role. The interviews were complemented by analysing data available on the Web pages of the Big 4 firms and published reports. This documentary evidence was collected and analysed to facilitate comparisons with the perceptions of the interviewees and validate the findings.

The data gathered was analysed using coding procedures comprising open, axial and selective coding (Strauss and Corbin, 1998). Open coding is an analytic process through which concepts are identified with their properties and dimensions. It is done by a line-by-line analysis method to provide certain concepts then grouped into categories. The process of axial coding is followed by undertaking relationships among the developed categories. At this stage, more interviews are conducted to reach a saturation level in which no more ideas can be developed. The third coding stage is selective coding as the process of integrating and refining the developed theory (Strauss and Corbin, 1998). The emerged theory was validated following the Strauss and Corbin approach (Elharidy et al., 2008).

The findings reflect our critical analysis for the participants' data. Gathering data from different groups of participants (regulators and auditors particularly) enables us not only to discuss different views on the role of independent regulators in promoting confidence in auditors, but to analyse these views and provide a better understanding of this role. We then recommend actions that need to be taken by the UK audit regulators to improve the auditors' choice and regain the public trust in auditors.

\section{Findings: FRC's strategies to restore public trust in auditors}

"The analyst reduces data from many cases into concepts and sets of relational statements that can be used to explain, in a general sense, what is going on" (Strauss and Corbin, 1998, p.145)

At the centre of this study are the main strategies followed by the FRC (as one of independent audit regulators in a major European country) to promote confidence in the audit market.

\footnotetext{
${ }^{3}$ Goddard and Assad (2006) argue that the interpretive approach was adopted to achieve a similar purpose (understanding the perceptions of the research participants).
} 
Three strategies were identified during the analysis process: assuring the quality of the audit firms' performance; increasing the transparency of the big audit firms; and reducing the barriers of entering the big audit market. Most of the FRC's projects focused on firms that audit public interest entities rather than small firms that only audit non-listed companies, which are still self-regulated by the professional bodies ${ }^{4}$. Our analysis was extended to explore the Big 4 firms' perceptions regarding such strategies, while a number of suggestions to improve the FRC's performance are provided in our conclusion.

\subsection{Improve quality of audit firms' performance}

One of the main strategies of the independent regulators is to improve the quality of audit process. Intensive inspections have been conducted to assure an acceptable level of quality within audit firms. For example, the FRC established the Audit Inspection Unit (AIU) to review the annual performance of firms that audit public companies. The AIU's annual reports are available to the public to provide clarity about the reliability of audit reports of listed companies. The AIU's inspection aims to identify the areas in which improvements are required in order to enhance the audit quality. Although the AIU's reports state that they are not intended to be a balanced scorecard or rating tool for inspected firms, these reports provide comparable information about the inspected firms and the quality of their auditing. This data can be used to differentiate among the Big 4 firms when companies need to select their external auditor.

Every year the AIU focuses on specific areas in the financial statements of audited clients in its inspection. However, the AIU's inspection only comprises of a review of the quality of selected audits of listed and other major public interest entities within the scope of independent inspection.

"It was felt that it would be beneficial to focus only on public interest entity audits" (Regulator).

This helps the AIU to focus uniquely on the major firms better to review the selected firms.

"It is not relevant to review a one-man audit firm and a firm that employs about 3000 audit staff by the same team" (Regulator).

The outputs of the AIU's inspection help the UK audit regulators to focus on areas of regulations that need further improvement. It is a mutual process between audit regulators and inspectors; the regulators issue regulations that assist the AIU's inspectors in doing their work (like the Audit Quality Framework), while the AIU's findings help the regulators to periodically revise their regulations and standards.

Views of the Big 4 firms towards the AIU

The Big 4 firms are satisfied with the independent inspectors. They argue that the AIU has enhanced the quality of the audit process in the last few years.

"It is a natural reaction of government for the accounting failures is to increase layers of regulation and that is effectively what happened" (Audit partner, Accounting firm A).

\footnotetext{
${ }^{4}$ However, the professional bodies are supervised by the FRC through the Public Oversight Board (POB).
} 
The independent oversight of the audit profession is a logical reaction by the government to protect public interests after the accounting failures that occurred recently.

"Our audits are better than six years ago (especially in the quality of documentation)." (Audit partner, Accounting firm A)

"The overall conclusion is the quality of audit work is good." (Audit partner, Accounting firm D)

However, not only the public can benefit from the AIU's inspection, auditors can also defend themselves in case of litigation. Big 4 partners argue that auditors should not be blamed for engagements inspected by the AIU.

"We welcomed the new regulators who will make the profession more credible through the independent reviewers." (Audit partner, Accounting firm C).

"The governmental audit oversight gives the audit firms a stamp of approval that says they are doing a good job, and removes any doubt that we aren't doing what we should do."(Audit partner, Accounting firm A)

The analysis indicates that the audit filling system is one of the main areas to have been enhanced. All audit procedures have to be documented - if they are not documented, it has not been done - to help auditors support their views and give evidence to justify decisions taken in the past.

"Actually having that documentation enables you to communicate with the regulator to support what you did and make sure that you don't admit something that you might have forgotten to mention because it was some time ago" (Audit partner, Accounting firm A).

The AIU's performance was also criticised. The AIU's inspectors do not always work effectively.

"I think they were ticking a box in many cases" (Audit partner, Accounting firm D).

Partners believe that their audit teams spend much time ticking the boxes or filling in forms.

"We spent much more time in dealing with all the regulations than we did in the past” (Audit partner, Accounting firm A).

"It would be good if they were concentrating all the time on what are the key risks in this audit. Sometimes they concentrate outside of that" (Audit partner, Accounting firm A).

Furthermore, there is a lack of materiality in the AIU's work. The inspection team spent a long time dealing with issues that are not key to the audit process.

"Their inspection process is very thorough and very detailed" (Audit partner, Accounting firm A).

"I think they will tend to pick up on something quite minor and make a bigger deal of it" (Audit partner, Accounting firm A). 
In contrast, the FRC's regulators emphasised that it is easy for audit partners to claim this because they know their clients very well. But the inspection teams only have limited time to review glossy financial statements that are well produced.

"They are very defensive... They may in certain circumstances say: this was the really difficult issue and this is how we dealt with it and that demonstrates we did a wonderful job." (Regulator)

It seems that more dialogue is needed between auditors and regulators. Auditors should clearly explain to the inspectors what they have done, while regulators should also consider the circumstances of the time of the audit, not the inspection.

Some audit partners believed that inspectors' work is very detailed; once the inspector found something - regardless of its materiality - they keep it in their mind all the time.

"What we found is that once they made a point, be it a valid one or not, they find it difficult to let it go" (Audit partner, Accounting firm A).

Two reasonable issues justify this criticism. The first is that the AIU starts looking at the audit files after the archiving period has finished because firms have two months from the date of signing the audit reports to archive and finalise everything on the file.

"If you look at their staff appraisal process, we agree that the firm should make some changes to the procedure. But we are already half way through next year's process, so the changes will have to happen later" (Regulator).

The second issue is that there are certain behavioural issues that firms find very difficult to rectify and improve over the years.

"Quality of substantive analytical review would be one that seems very difficult for people to do well enough. Some firms have now said it is just too difficult, every time the AIU comes along and says we have not done it well enough" (Regulator).

Some auditors feel that the inspection team feels obliged to unearth a problem as they are accountable and they have to find some issues.

"It is difficult for them to walk away and say I have no issues to report" (Audit partner, Accounting firm A).

Furthermore, the Big 4 believe that greater attention should be given to corporate governance as the accounting expectations gap is higher than the auditing gap.

"We should improve corporate governance first." (Audit partner, Accounting firm C).

The audit firms were concerned that audits often depend on personal judgments and inspectors should consider the circumstances of the auditor's judgment, before rather than after.

"Audit is about judgment in a lot of cases; often, we're going to have different views on judgment." (Audit partner, Accounting firm A) 
The Big 4 partners stressed that they may change their documentation systems as a result of the AIU's inspection. However, their audit opinions have never been changed as a result of the new regulators.

"There are things that we do and we tell teams to do, just to keep our regulator happy." (Audit partner, Accounting firm A)

"I don't think we change our opinion because there is a regulator review" (Audit partner, Accounting firm A).

There was a different view between the audit partner and the inspection team on a specific issue, where the audit partners provide all the documents and evidence that support their view.

"I think we would always go with our judgment, what we think is right." (Audit partner, Accounting firm A)

Some partners raised a question about the rotation of regulators in different positions and how this could improve the quality of the audit oversight system.

"I think it is important that you don't get stuck for too long without a new experience." (Audit partner, Accounting firm C).

\subsection{Increasing transparency in the big audit firms}

A better understanding of how the big audit firms work can help to promote public confidence, enhance choice in the audit market, and encourage mid-sized firms to enter the market (Basel, 2008).

But what type of information do regulators feel will improve public trust in auditors and enhance choice in the audit market? Analysing the FRC's projects identifies three types of information that need to be more understandable: information about the big audit firms' governance structure; the key factors that affect the auditors' competition in UK capital market; and the main ways by which the audit firms consider the public interest in their own decisions. Each type is discussed as follows.

\subsubsection{The big audit firms' governance structure}

The Statutory Auditors Instrument (2008) requires all auditors of UK companies with securities traded on a UK regulated market to produce annual transparency reports (POB, 2010:a). The mandated reports should provide detailed information about the legal and governance structures of audit firms (POB, 2010: b). The usefulness of the transparency reports were confirmed by the interviewed partners of the Big 4 firms.

“We've been doing it for a long time." (Audit partner, Accounting firm A)

"It is sort of double standards to say we are keeping everything about us secretive, at the same time insisting that clients disclose this, that and the other." (Audit partner, Accounting firm A)

However, the auditors believe that more work is required to enhance the quality of these reports. 
"It is a good thing that people understand what our processes are, procedures, everything" (Audit partner, Accounting firm C).

"There is more we can do on our transparency report, and we are working on that" (Audit partner, Accounting firm A).

\subsubsection{Key drivers of competition in the UK audit market}

In 2009, the POB carried out an exercise to understand how auditors and audit committees assess audit quality in a tendering process. It was clear from the exercise that the firm's size and brand are the main drivers of audit quality (FRC, 2010:b). However, the Big 4 partners provided additional groups of audit market drivers.

The quality of personnel and good relationships with the clients are drivers that can attract the clients to choose specific auditors.

"The mid-sized firms need to get the right people to serve global companies which are seeking experts for their business." (Audit partner, Accounting firm D).

"It's all about relationships. I'll have on-going relationships with clients that have no intention of putting their audit out just now, but I am there either helping them with other services, or building relationships so that if something goes wrong with their existing audit relationship, they have already got a known relationship and trust which we can work from." (Audit partner, Accounting firm D).

Understanding such drivers helps mid-sized firms to change their strategies and better to compete in the big audit market. It also further enhances choice decisions in the audit market.

\subsubsection{Assuring that public interest is considered inside firms' decisions}

Auditors have social responsibilities towards the public who trust them and rely on their reports when taking their investments' decisions (Suddaby et al., 2007). Thus, in January 2010, the FRC published the audit firm governance code that aims to provide a formal benchmark of good governance practice (FRC, 2010:a).

One of the key features of the code is the mandatory appointment, by the audit firms, of independent non-executives who can be a witness to a firm's commitment to the public interest.

Big 4 partners believe that independent non-executives can add value to the audit firms' governance and help the board of directors with their experiences.

"We are not worried about the new INEs; it helps the external credibility of our organisation." (Audit partner, Accounting firm A)

"I think it is dangerous for an organisation to become too insular." (Audit partner, Accounting firm C)

Certain audit firms have already had long term non-executives within their structure, with different committees in their governance structure playing similar roles. 
"Beside the board of directors, we already have different committees similar in their nature to the new non-executives." (Audit partner, Accounting firm A)

We argue that time is needed to evaluate the non-executives' performance and the extent to which they can help the quality of the audit process and protect public interest.

"We just need to see how it goes and see what it does because we don't know when we will first do a report on it." (Audit partner, Accounting firm C)

"The whole area is brand new; it will take time to be developed. Who knows what will happen in the future?" (Regulator)

However, we raise a question about the independence of the non-executives and the extent to which they can provide reliable information because at the end they are selected and paid by the firms themselves.

"You would hope their reputation would be more important and that if there was a real problem that they would either sort it out or would resign." (Regulator)

"This is a new concept and we have to see how it works." (Regulator)

\subsection{Reducing barriers to entering the big audit market}

Two types of barriers prevent mid-sized firms from entering the big audit market: financial barriers and risk barriers (Oxera, 2006). The following sub-sections give some examples to explain how the FRC acted to reduce such barriers.

\subsubsection{Reducing risk barriers}

Auditors have unlimited liability to their audit clients and third parties if they fail to provide an appropriate audit opinion. This is one of the main reasons why mid-size audit firms are discouraged from competing in the big audit market as the potential compensation (in case of an audit failure) is beyond their financial means. The UK Companies Act 2006 allows audit firms to limit their liabilities to their clients after approval of the clients' shareholders.

The FRC (2008:b) provides guidance on auditor liability limitation agreements explaining how these agreements can be implemented to provide valuable assistance to company directors and shareholders. However, the FRC reported that no major listed companies are known to have entered into a limited liability agreement (FRC, 2010: b).

The Big 4 partners argued that the largest listed companies do not enter these agreements as most of them are listed in the US capital market, which does not allow auditors or managers to do so. As a result, when the largest companies do not have these agreements, the next group of listed companies will not be willing to be the leaders.

"I think there were one or two who were willing to be the leaders in changing the market practice." (Audit partner, Accounting firm A)

It might not be fair that auditors are being held responsible for the errors of other parties; they should be responsible for their own errors. 
"The point of liability caps is not that we shouldn't have liability, it's that we shouldn't have other's liability as well as ours." (Audit partner, Accounting firm B).

"We think it is a very important piece because it stops the meltdown on the auditors being blamed." (Audit partner, Accounting firm C).

Furthermore, auditors' limited liability could increase the effectiveness of choice in the UK audit market.

"We believe they will play an important role in bolstering competition and choice in the market" (Accounting firm C).

Limited liabilities will not affect the quality of the audit process because the audit regulatory framework would not be changed accordingly.

"It doesn't change our regulatory environment that says we have to comply with these standards" (Audit partner, Accounting firm A).

Auditors believe that it is better to mandate these agreements by the law; otherwise managers or shareholders will not enter voluntarily into such agreements. In some European countries (i.e. Germany) auditors have a limited liability as part of the law (Weber et al., 2008).

"The majority were much happier to stay in a body and not have something that could be an issue with their shareholders or investors. So the majority wouldn't really entertain being voluntarily moved across." (Audit partner, Accounting firm A)

"Where limited liability regimes exist in countries, they are mandated by law and so where they are not mandated, who is going to take it up?" (Audit partner, Accounting firm C).

One of the main reasons why companies might enter into these agreements is to enable them to obtain audit services at an acceptable price (FRC, 2008:b). However, some Big 4 partners stressed that fees are determined by the efforts made to complete the audit process and market circumstances, regardless of auditors' liabilities.

"We never reduce our fees for the limited liability. This is not an insurance policy." (Audit partner, Accounting firm A)

"Fees and liabilities don't come together. The fees are the work we do. It is not a risk premium." (Audit partner, Accounting firm $C$ )

\subsubsection{Reducing the financial barriers}

One of the significant barriers to entering the big audit market is the need for substantial resources and expertise to attract international companies (Oxera, 2006). The ability of existing audit firms to raise their financial resources is restricted by the UK Companies Act that requires audit firms to be controlled by qualified auditors. The FRC (2008:a) argues that any changes in the current ownership rules needs to be considered as part of a package of measures to improve choice. The paper identified three areas of risk that threaten the audit market: an increased concentration in the market; financial considerations associated with 
outside ownership driving down audit quality; and outside ownership leading to shortages of highly skilled auditors.

The Big 4 partners argue that it is not easy to accept the proposed rules as this will affect audit independence.

"The risk that it could be perceived that they exercise undue influence on the auditor to give a certain opinion on a set of accounts" (Audit partner, Accounting firm A)

We believe that if the rules allowed non-participants to invest in audit firms, they would invest in the Big 4 firms rather than medium-sized firms, which will not solve the higher concentration problem in the market.

Our analysis identifies hiring the right people who have expertise in a wide range of industries as another barrier to the audit market.

"The main constraint is having the right people. You can try and compete, but you are more likely to win work if you've got people who have experience in the sector." (Audit partner, Accounting firm C).

\section{Discussion and Conclusion}

This study aimed to analyse the effectiveness of the FRC's strategies in restoring public trust in auditors and to understand auditors' perceptions of these strategies. Three strategies have been identified: improving the audit quality; increasing the transparency of the big audit firms; and reducing the barriers to competing in the major audit market.

For the first strategy, we conclude that the annual inspections of the Audit Inspection Unit's team have increased audit quality. In particular, great attention has been paid to the documentary system of audit firms so every single procedure has to be documented. Participants stressed that more systematic and restricted documentation systems have been applied by inspected firms to fulfil the FRC's inspectors' requirements. Although auditors feel they have spent more time completing audit files and ticking boxes, this helps them to justify their judgements to outsiders. This is consistent with the literature (i.e. Casterella et al., 2009; Tsau, 2011) where increased audit quality follows the establishment of audit oversight systems in different regions.

Our analysis was extended to include the auditors' views to the AIU's inspection and their members of staff, providing a unique opportunity to discuss auditors' criticisms of AIU inspectors and how inspectors defended themselves. We argue that there is a gap between auditors and AIU's inspectors. Auditors believe that inspectors need to pay more attention to core issues rather than wasting auditors' time on smaller issues; they also have to consider associated circumstances at the time of audit rather than inspection. In parallel, auditors have to provide more details to inspectors on the main issues of audit files.

For the second strategy, we concluded that the FRC's efforts successfully offer more information for public about the audit market. Extra information has been available to help 1) public to know more about audit firms' governance structures 2) mid-size firms to know more about competition's drivers in the market 3) audit clients to compare potential auditors. For example, a set of projects has been established by the FRC which mandated audit firms to provide more disclosures about their strategic approach and internal control systems. As cited 
in Deumes et al. (2012), Petersen and Zwirner (2009) found that the extent of disclosures is positively correlated with audit quality and audit size as well.

Compared with regulators in different regions (i.e. U.S.), we noted that the FRC provides more information about inspected audit firms. In the U.S., the PCAOB hides areas that need improvement in audit firms' performance for one year; they only disclose them publicly if inspected firms do not take corrective actions. The FRC's inspection reports inform the public of all areas of audit firms' performances. However, we questioned the extent to which investors depend on FRC's reports; a matter for future research. Furthermore, in 2010 the FRC was the first audit regulator to apply the UK Audit Firms Governance Code, when only the UK and Netherlands mandated their biggest audit firms to apply such code. The code requires audit firms to disclose publicly more information about their strategies and auditing approaches.

In addition, the FRC (2010: b) argues that firms' size and brand are the main competition drivers in the market, although our participant partners stressed that people and business relationships are the dominated ones. Changing sizes or brands may need a lot of investment. However, hiring and developing highly skilled people needs less investment and makes a bigger difference.

For the third strategy, limited resources and unlimited liability of auditors have been identified as the main barriers discouraging mid-sized firms to compete in the big audit market. Allowing non-professionals to invest in audit firms was debated by audit regulators to provide more funds to the mid-size firms. However, our findings suggest that the FRC might avoid taking this action to allow non-practitioners to own audit firms so creating risks unmitigated by relevant safeguards. None of the leading markets in the US or Europe permit non-practitioners to invest/control audit firms. Non-practitioners' owners may lead the profession to be driven by financial considerations rather than by ethics, consistent with Oxera (2007) who suggests negative impacts on quality of allowing non-practitioners to own audit firms. Most importantly, such allowance may increase the gap between the Big 4 firms and the mid-sized firms. The Big 4 may be more attractive to investors and more funds will be available to the large rather than the mid-sized firms.

For unlimited liabilities, auditors can only limit their liabilities after clients' shareholder approvals; we believe that this should be changed. Mandating auditors' limited liabilities might reduce the barriers of entering the big audit market and increase the number of big players. Mid-size firms would be encouraged to take the risk of auditing leading corporates if they knew that they will be accountable only to their work.

In conclusion, for more than ten years, many projects have been established by the FRC to restore public trust in auditors. Partners of the Big 4 believe that the FRC's projects are effective in improving the audit quality as well as providing wider public information about the audit firms. Such projects enable the UK capital market to be more reliable and trusted. However, as explained above, more actions need to be taken to enhance the choice in auditors and increase the number of big audit firms that compete in the market. Table 1 presents a number of actions that need to be taken by the FRC suggested in this study. 
Table 1: The FRC's projects to rebuild public trust in auditors and suggested actions

\begin{tabular}{|c|c|c|c|c|}
\hline FRC's projects & Purpose & Criticism/Shortage & Suggested Action & Expected outcome \\
\hline $\begin{array}{l}\text { 1. Inspecting audit } \\
\text { firms. }\end{array}$ & Improved audit quality & $\begin{array}{l}\text { Inspected firms have } \\
\text { concerned regarding the } \\
\text { inspection's process. }\end{array}$ & $\begin{array}{l}\text { FRC's inspectors need to } \\
\text { know auditors' feedback. }\end{array}$ & $\begin{array}{l}\text { Conducting more } \\
\text { effective inspections. }\end{array}$ \\
\hline $\begin{array}{l}\text { 2. Reviewing audit } \\
\text { competition's drivers }\end{array}$ & $\begin{array}{l}\text { Increased } \\
\text { transparency }\end{array}$ & NA & $\begin{array}{l}\text { We suggest more drivers: } \\
\text { people and relationships }\end{array}$ & Better transparency \\
\hline $\begin{array}{l}3 . \quad \text { Mandating } \\
\text { transparency reports in }\end{array}$ & $\begin{array}{l}\text { Increased } \\
\text { transparency }\end{array}$ & NA & NA & NA \\
\hline $\begin{array}{l}\text { 4. Firms' ownership's } \\
\text { rules }\end{array}$ & $\begin{array}{l}\text { Increased auditing } \\
\text { competitions }\end{array}$ & $\begin{array}{l}\text { Non-practitioners } \\
\text { invest more in the Bill } 4 \\
\text { firms as they are more } \\
\text { profitable; this will reduce } \\
\text { the competition. This } \\
\text { affects auditors' } \\
\text { independence. }\end{array}$ & Avoiding this debate. & $\begin{array}{l}\text { Mitigate a threat of } \\
\text { auditors' independence. }\end{array}$ \\
\hline $\begin{array}{lr}5 . & \text { appointing } \\
\text { independent } & \text { non- } \\
\text { executives } & \\
\end{array}$ & $\begin{array}{l}\text { Increased } \\
\text { transparency }\end{array}$ & $\begin{array}{l}\text { Non-executives are selected } \\
\text { and paid by audit firms }\end{array}$ & $\begin{array}{l}\text { investors should be } \\
\text { consulted in the INEs' } \\
\text { appointment }\end{array}$ & $\begin{array}{l}\text { Increase the reliability of } \\
\text { information provided } \\
\text { about big audit firms. }\end{array}$ \\
\hline $\begin{array}{l}\text { 6. limited liability } \\
\text { agreements }\end{array}$ & $\begin{array}{l}\text { Increased auditing } \\
\text { competitions }\end{array}$ & $\begin{array}{l}\text { Shareholders never agreed } \\
\text { to apply such agreements.. }\end{array}$ & $\begin{array}{l}\text { Mandating Auditors' } \\
\text { limited liabilities }\end{array}$ & $\begin{array}{l}\text { Increase the number of } \\
\text { big audit firms }\end{array}$ \\
\hline
\end{tabular}




\section{REFERENCES}

Abernathy, J. L., Barnes, M., \& Stefaniak, C.,A (2013) 'Summary of 10 Years of PCAOB Research: What Have We Learned?', Journal of Accounting Literature, http://dx.doi.org/10.1016/j.acclit.2013.10.002.

Audit Inspection Unit [AIU] (2011) 'Annual Report 2010/2011', available at www.frc.org.uk - (2010) 'Annual Report 2009/2010', available at www.frc.org.uk

Auditing Practices Board [APB] (2010) 'The Provision of Non-Audit Services by Auditors' available at: $\underline{w w w . f r c . o r g . u k}$

(2008) 'Ethical Standard 5 (revised): non-audit services provided to audited entities', available at: www.frc.org.uk.

Basel Committee on Banking Supervision (2008) 'External Audit Quality and Banking Supervision', Bank for International Settlements.

Basioudis, I.G., Papakonstantinou, E. and Geiger A. (2008) 'Audit Fees, Non-Audit Fees and Auditor Going-Concern Reporting Decisions in the United Kingdom', Abacus, 44 (3), pp. 284-309.

Bather, A. and Burnaby, P. (2006) 'The Public Company Accounting Oversight Board: national and international implications', Managerial Auditing Journal, 21 (6) pp. 657699.

Carson, E. (2009). "Industry Specialization by Global Audit Firm Networks", The Accounting Review, 84(2), pp. 355-382.

Casterella J., Jensen K. and Knechel R. (2009). "Is Self-Regulated Peer Review Effective at Signaling Audit Quality?", The Accounting Review, 84(3), pp. 713-735.

Cooper, D. and Robson, K. (2006) 'Accounting, professions and regulation: locating the sites of professionalization', Accounting Organizations and Society, 31, pp. 415-444.

DeFond, M.L. and Francis J.R. (2005) 'Audit Research after Sarbanes-Oxley?' Auditing: A Journal of Practice \& Theory, 24, Supplement, pp. 5-30.

Duff, A. (2009) 'Measuring Audit Quality in an Era of Change: An Empirical Investigation of UK Audit Market Stakeholders in 2002 and 2005', Managerial Auditing Journal, 24 (5), pp. 400-422.

Elharidy, A.M., Nicholson, B. and Scapens R.W. (2008) 'Using Grounded Theory in Interpretive Management Accounting Research', Qualitative Research in Accounting and Management, 5 (2) pp. 139-155.

Eilifsen, A. and Knivsflå, K. (2013) "How Increased Regulatory Oversight of Nonaudit Services Affects Investors' Perceptions of Earnings Quality”, AUDITING: A Journal of Practice \& Theory, 32 (1), pp. 85-112

European Commission [EC] (2009) 'Consultation on Control Structures in Audit Firms and their Consequences on the Audit Market', available at: www.frc.org.uk

(2008) 'Commission Recommendation Concerning the Limitation of the Civil Liability of Statutory Auditors and Audit Firms', Brussels available at: http://ec.europa.eu

Evans, R., Boster, R., Gradison, B. (2011) "Increasing Transparency: A Prototype of the Non-public Portions of PCAOB Large-Firm Inspection Reports", Current Issues in Auditing, 5 (1), pp. A1-A21.

Financial Reporting Council (FRC) (2010:a) 'The Audit Firm Governance Code', available at: www.frc.org.uk

(2010:b) 'Choice in the UK audit Market: fifth progress report', available at: $\underline{w w w . f r c . o r g . u k}$ 
available at: www.frc.org.uk

(2009) 'Regulatory Strategy-Our Role and Approach',

(2008:a) 'Choice in the UK audit Market: progress report and further consultation', available at: www.frc.org.uk

(2008:b) 'Guidance on Auditor Liability Limitation

Agreements', available at: www.frc.org.uk

$\underline{\text { www.frc.org.uk }}$

(2008:c) 'Audit Quality Framework', available at:

(2007) 'Choice in the UK audit Market: final report of the Market Participant Group', available at: www.frc.org.uk

Firth, M. (2002). "Auditor-provided consultancy services and their associations with audit fees and audit opinions", Journal of Business Finance \& Accounting 29, pp. 661-693.

Francis, J.R. and Yu, M.D. (2009) 'Big 4 Office Size and Audit Quality', The Accounting Review, 84 (5), pp. 1521-1552.

Geiger, M. and Raghunandan, K. (2005) 'Recent changes in the association between bankruptcies and prior audit opinions', Auditing: A Journal of Practice \& Theory, 24 (1) pp. 21-35.

Geiger, M. and Rama, D. (2006) 'Audit Firm Size and Going-Concern Reporting Accuracy', Accounting Horizons, 20 (1), pp. 1-17.

(2003) 'Audit Fees, Nonaudit Fees, and Auditor Reporting on Stressed Companies', Auditing: A Journal of Practice \& Theory, 22 (2), pp. 53-69.

Glaser, B. (1992) 'Basics of grounded theory analysis', Sociology Press.

Glaser, B. and Strauss, A. (1967) 'The discovery of grounded theory: strategies for qualitative research', Weidenfeld and Nicolson, London.

Goddard, A. and Assad, M.J. (2006) 'Accounting and Navigating Legitimacy in Tanzanian NGOs', Accounting, Auditing and Accountability Journal, 19 (3) pp.377-404.

Gardison, B. and Boster, R. (2010) “The PCAOB's First Seven Years: A Retrospection”, Current Issues in Auditing, 4 (1), pp. A9-A20

Gurd, B. (2008) 'Remaining Consistent with Method? An Analysis of Grounded Theory Research in Accounting' Qualitative Research in Accounting and Management, 5 (2) pp.122-138.

Hanney, B. (2006), “Accounting firms with 'core values' perform better", Accountancy, November, available at: www.accountancymagazine.com.

Hazgui, M., Lesage, C. and Pochet, C. (2011). "Independent Audit Oversight Authorities: A Comparative Study of The United States, The United Kingdom and France", 34th Annual European Accounting Association Conference, Rome, Italy.

Hoitash, R., Hoitash, U. and Bedard, J.C. (2008). "Internal Control Quality and Audit Pricing under the Sarbanes-Oxley Act”, Auditing: A Journal of Practice \& Theory, 27(1), pp. 105-126.

Hope, O. and Langli, J.C. (2010) "Auditor Independence in a Private Firm and Low Litigation Risk Setting”, The Accounting Review, 85(2), pp. 573-605.

Humphrey, C., Loft, A., Woods, M. (2009) "The global audit profession and the international financial architecture: Understanding regulatory relationships at a time of financial crisis", Accounting, Organizations and Society, vol. 34, no. 6-7, pp. 810-825.

International Federation of Accountants (2013) 'Consulates on Audit Quality Framework', available at: $\underline{w w w . i f a c . o r g}$.

International Organization of Securities Commissions (IOSCO) (2010) 'Transparency of Firms that Audit Public Companies', available at: www.iosco.org 
(2009) 'Exploration of Non-Professional Ownership Structures for Audit Firms: Consultation Paper' available at: www.iosco.org

Institute of Chartered Accountants in England and Wales (ICAEW) (2012) 'From Perception to Perfection', The Audit Quality Forum, available at: http://www.icaew.com/en/technical/audit-and-assurance/faculty

Kinney, JR., Palmrose, Z. and Scholz, S. (2004). "Auditor Independence, Non-Audit Services, and Restatements: Was the U.S. Government Right?", Journal of Accounting Research, 42(3), pp. 561-588.

Knechel, R. (2009) 'Audit Lessons from the Economic Crisis: Rethinking Audit Quality', Inaugural Lecture, Maastricht University.

Larcker, D.F. and Richardson, S.A. (2004) 'Fees Paid to Audit Firms, Accrual Choices, and Corporate Governance', Journal of Accounting Research, 42 (3), pp. 625-658.

LoBiondo-Wood, G. and Haber, J. (1994) 'Nursing Research: Methods, Critical Appraisal, and Utilization', Mosby, St Louis, USA.

London Economics (2006) 'Study on the economic impact of Auditors' Liability Regimes' available at: www.frc.org.uk.

Lu, T. and Sapra, H. (2009) 'Auditor Conservatism and Investment Efficiency', The Accounting Review, 84 (6), pp. 1933-1958.

Nelson, M. (2009) 'A model and literature review of professional skepticism in auditing', Auditing: A Journal of Practice \& Theory, 28 (2), pp. 1-34.

Oliver, C. (1991) 'Strategic responses to institutional processes', Academy of Management Review, 16 (1), pp. 145-179.

Oxera (2006) 'Competition and Choice in the UK Audit Market' available at: www.frc.org.uk.

Oxera (2007) 'Ownership Rules of Audit Firms and their Consequences for Audit Market Concentration' European Commission available at: www.ec.europa.eu.

Patterson, E.R. and Smith, J.R. (2007) 'The Effects of Sarbanes-Oxley on Auditing and Internal Control Strength', the Accounting Review, 82 (2) pp. 427-455.

Pierce, B. and Sweeney, B. (2004). "Cost-Quality Conflict in Audit Firms: An Empirical Investigation", European Accounting Review, 13(3), pp. 415-441.

Professional Oversight Board [POB] (2010:a) 'Key Facts and Trends in the Accountancy Profession' available at: www.frc.org.uk

(2010:b) 'Transparency Reporting by Auditors of Public Interests Entities: Review of Mandatory Reports' available at: www.frc.org.uk

Ruiz-Barbadillo E., Gomez-Aguilar N., De Fuentes-Barbera C. and Garcia-Benau M.A. (2004) 'Audit Quality and the Going-Concern Decision Making Process: Spanish Evidence', European Accounting Review, 13(4), pp.597-620.

Samsonova, A. (2009) 'Local Sites of Globalisation: A Look at the Development of a Legislative Framework for Auditing in Russia', Critical Perspective on Accounting, 20, pp. 528-552.

Shapiro, B., Matson, D. (2008) 'Strategies of resistance to internal control regulation', Accounting, organizations, and society, 33 (2-3), pp. 199-228.

Sikka, P. (2009) "Commentary on Roy Suddaby, Yves Gendron and Helen Lam "the Organizational Context of Professionalism in Accounting", Accounting, Organisations and Society, 34 (3-4), pp. 428-432.

Strauss, A. and Corbin, J. (1998) 'Basics of Qualitative Research: Techniques and Procedures for Developing Grounded Theory', Second Edition, London, Sage. 
(1990) 'Basics of Qualitative Research: Grounded Theory Procedures and Techniques', Sage, Newbury Park, CA.

Suddaby, R., Gendron, Y., and Lam, H. (2009) 'The organizational context of professionalism in accounting', Accounting Organizations and Society, 34(3-4), pp. 409-427

Suddaby, R., Cooper, D. and Greenwood, R. (2007) 'Transnational Regulation of Professional Services: Governance Dynamics of Field Level Organizational Change', Accounting, Organizations and Society. 32 (4-5), pp. 333-362.

Weber, J., Willenborg, M. and Zhang, J. (2008) 'Does Auditor Reputation Matter? The Case of KPMG Germany and ComROAD AG.', Journal of Accounting Research, 46, pp. 941972. doi: 10.1111/j.1475-679X.2008.00298.x 